\title{
Foucault’n diskurssista tervetullut
} \section{suomennos}

\author{
Michel Foucault: Tiedon arkeologia. Suomennos Tapani \\ Kilpeläinen. Vastapaino 2005. 275 s.
}

\begin{abstract}
Kannattaako klassikkoja suomentaa, kun alan harrastajat ovat jo tutustuneet teoksiin englanniksi? Kannattaa, koska Michel Foucault'n (1926-1984) Tiedon arkeologian englanninnos ei välttämättä ole yhtä tasokas kuin nyt käsillä oleva suomennos. Suurilla ja itseriittoisilla kielialueilla käännökset eivät useinkaan ole yhtä hyviä, kuin mihin meillä on Vastapainon, Gaudeamuksen, Tutkijaliiton ja muutamien muiden pienten ja keskisuurten kustantajien ansiosta totuttu.
\end{abstract}

Toinen peruste klassikkojen suomennokselle on kielipoliittinen. Yliopistoissa ja niin sanotuissa soveltavien tieteiden yliopistoissa suomalaisten opettajien ja suomalaisten opiskelijoiden välinen kommunikaatio käy enenevässä määrin maailman yleisimmällä kielellä broken Englishillä, tai sujuvammalla mutta yhtä lailla kapealla vaihto-oppilasenglannilla. Meille kerrotaan jatkuvasti, että äidinkielen käyttö tieteellisissä yhteyksissä on luuserien puuhaa. Jos kuitenkin ajattelemisella, lukemisella ja kirjoittamisella on vähänkään keskinäistä yhteyttä, sopii toivoa, että ajattelun, lukemisen ja kirjoittamisen kieli olisi sama. Silloin emme hukkaa sanoja, asioita tai asioiden järjestystä, joiden sävyjä voi ymmärtää vain ja ainoastaan omalla äidinkielellään, riippumatta siitä, kuinka sujuvaa vieraan kielen käyttö on.
Foucault kehitteli diskurssin käsitettään Tiedon arkeologiaa edeltävässä teoksessaan Les Mots et les Choses (engl. The Order of Things). Foucault jäljittää unohtumattomalla tavalla inmistieteiden muotoutumista ja epistemologiaa. Hän tutki, kuinka eläviä olentoja, vaurautta ja kieltä koskeneet tieteelliset totuuspelit muovasivat perustakseen "ihmisen".

Ihmistieteiden historiallisten kerrostumien kaivaukset etsivät oppialojen ja rajattujen diskurssien perustana olevaa tiedon ja totuuden rakennetta, koodia, joka tekee mahdolliseksi ja sallii tietää jotakin inmisestä. Foucault päätyi siihen, että "ihminen" tieteellisen diskurssin kohteena on yllättävän uusi keksintö.

\section{Diskurssit ja niiden rajaukset}

Foucault ei Tiedon arkeologiassaan (L'archéologie du sa-voir, 1969) viittaa diskurssin käsitteellä mihin tahansa keskusteluun, vaan yhteiskunnalliseen tai tieteelliseen puheeseen, keskusteluun ja käytäntöihin, joilla on oma kohteensa, kielensä, argumentaationsa ja sovellusalueensa. Lausumista rakentuva diskursiivinen muodostelma luo oman kohteensa ja hyväksyttävän puhetapansa. Aatehistoriasta poiketen Foucault ei tutki suurmiesten aja- tusten leviämistä tai tietyn diskurssin syntyä, vaan diskurssia tarkastellaan "ilmenemisensä silmänräpäyksessä” (s. 39).

Kun aatehistoriassa diskursiivista muodostelmaa pidetään dokumenttina jostakin tekstin ulkopuolisesta, tiedonarkeologiassa teksti on monumentti: diskursiivinen muodostelma sisältää jo itsessään kaiken merkityksellisen, eikä tekstin avulla pyritä tekemään historiallisia tai muita tulkintoja sen ulkopuolella olevasta (s. 181-182). Teksti on samanaikaisesti sosiaalisen todellisuuden tuote ja tuottaja. Tästä seuraa, ettei foucault'laisessa diskurssianalyysissä tutkita subjekteja tai tietoisuutta, vaan anonyymeja tekstejä.

Diskurssissa kyse on totuuden ja tiedon rakenteista, joita tieteen tekijä ei voi tiedostaa eikä artikuloida ja jotka rakentavat mahdollisuuden tieteelliseen tietoon: kohteet, käsitteet, argumentoinnin tavat, havainnoinnin tavat eli katseen sekä "oppineen" aseman. Épistémè viittaa anonyymeihin diskursiivisiin käytäntöihin, puhetapojen säännönmukaisuuksiin, joihin tiedon ja totuuden muodostumat eli tieteet on upotettu (s. 248-249).

Épistémè tarkoittaa tiedon apriorisia ehtoja. Tämä a priori ei kuitenkaan ole annettu, formaalinen eikä transsendentaalinen, vaan aina historiallisiin käytäntöihin sidottu. Ajasta ja paikasta riippuu, millaisia ovat hyväksyttävät tiedon kohteet ja tiedon luomisen menetelmät, 
ylipäänsä se mikä käsitetään ja tunnustetaan tiedoksi. Diskursiivinen käytäntö määrittää mitä, miten ja millä oikeutuksella joku voi sanoa jotakin.

Tieto luo tilaa vallan toiminnalle ja valta luo uusia tiedon kohteita. Tarvitseeko erikseen sanoa, että viime vuosien OECD:läistä koulutuspoliittista keskustelua on tavattoman kiintoisaa katsella foucault'laisten silmälasien läpi?

Diskurssin syntymisessä on yhtä lailla olennaista, mitä siitä rajataan pois, kuin mitä siihen hyväksytään. Diskurssista pois rajaamiseen Foucault esittää kolme tapaa, joiden tarkoituksena on suojella diskurssia ja kehittää sille oma identiteetti. Ensinnäkin kiellot estävät keskustelun, jos aiheet, ilmaisut tai tilanteet eivät ole soveliaita. Toinen keino on erottaa toisistaan järkevä ja hullu puhe. Kolmas tapa rajata diskurssi on normatiivinen toden ja valheen ero. Tieteellisessä keskustelussa tämä tarkoittaa, että on sovittu tiettyjen peruskäsitteiden sisällöstä tai tosiasioista. Diskursiiviset rajauskäytännöt tehoavat, jos niille on olemassa institutionaalinen perusta ja sellaisia yhteiskunnallisia käytäntöjä, joissa ne voivat konkretisoitua.

Arkeologisella menetelmällä kaivetaan esiin jatkuvuuden sijastakatkoksiaja Gaston Bachelardin kuvaamia "kynnyksiä", jotka keskeyttävät tiedon hitaan ja jatkuvan kasautumisen ja rikkovat niiden kehityksen. Katkokset irrottavat tiedot niiden empiirisestä alkuperästä ja alkuperäisistä perusteluista (s. 12).

Kun synnytetään uusia soveltavia tieteenaloja hallinnollisin toimin tai tietyn ammattikunnan kohennukseksi tieteen sisäisen kehityksen sijasta, on hyödyllistä tutustua niihin kynnyksiin, joita diskursiivinen muodostelma joutuu Foucault'n mukaan ylittämään, jotta siitä tulisi tiede: positiivisuuden eli varmuuden, epistemologisoinnin, tieteellisyyden ja formalisoinnin kynnykset (s. 242).

Vain yksi tiede eli matematiikka on kerralla voinut ylittää nämä neljä kynnystä. Sellaisenaan kynnysmallia ei voi soveltaa ihmis- ja yhteiskuntatieteiden kehitykseen.

\section{"En ole tätä enkä tuota"}

Foucault ei ollut tyytyväinen kirjaansa Les Mots et les Choses/The Order of Things, koska hän ei onnistunut esittämään tiedonarkeologista metodiaan riittävän selkeästi tässä muuten lähtemättömän jäljen luoneessa tutkimuksessaan. Saamansa kritiikin ja harjoittamansa itsekritiikin vuoksi hänen täytyi systematisoida metodiaan. Lisäksi hänen piti kiireesti pätevöityä hänelle mittatilauksena valmisteltuun professuuriin Ranskan tärkeimmässä opinahjossa Collège de France'issa. Foucault kuvaa aiempia teoksiaan varovaisempaa tapaa kirjoittaa Tiedon arkeologiaa:

"Teksti ottaa joka hetki etäisyyttä, varmistaa selustansajoka puolelta, hapuilee kohti rajojaan, kolhiutuu siihen, mitä ei halua sanoa, kaivaa kuoppia merkitäkseen oman polkunsa. Se ilmoittaa joka hetki mahdollisesta sekaannuksesta. Se torjuu identiteettinsä sanomalla etukäteen: en ole tätä enkä tuota. Yleensä teksti ei ole kriittinen" (s. 29).

Kirja on varmasti hyödyllinen eri alojen diskurssien tutkijoille, mutta yllä oleva ironinen ja puolustautuva sitaatti jo antaa ymmärtää, että käsillä on jokseenkin vaikeaselkoinen ja paikoin skolastisen tuntuinen teos. Liittymäkohtia elävän elämän diskursseihin on vaikea nähdä. Tämän vuoksi kirjan ajatuskulkua on vaikea tiivistää ymmärrettävästi. Turhaan saa hakea Foucault'lle muutoin ominaista näkemyksellisyyttä ja hulppeita yleistyksiä - jotka ovat tosin joskus niin hulppeita, etteivät historioitsijat välttämättä innostu niistä yhtä paljon kuin ihmis- ja yhteiskuntatieteilijät.

Tiedon arkeologian ymmärrettävyys lisääntyy huomattavasti Les Mots et les Choses/The Order of Things -teokseen tutustumisen jälkeen. Suomennosta odotellaan tänä vuonna Vastapainolta. Lisäksi apuna on hyvä olla jokin Foucault-selitysteos, joita voi pitää jo omana genrenään. Suomeksi tällaisia ovat muun muassa Martin Kuschin Tiedon kentät ja kerrostumat (Pohjoinen) sekä Sari Husan ja Ilpo Helénin artikkelit. Aivan mainio on Vastapainon julkaisema Didier Eribonin Foucaultelämäkerta.

JUSSI ONNISMAA 